J. Japan. Assoc. Min.

Petr. Econ. Geol.

67, $63-75,1972$

\title{
XONOTLITE FROM THE OHMI DISTRICT, NIIGATA PREFECTURE, JAPAN*
}

\author{
NaOya Imai**, RyoheI Otsuka**, Kazuya Chihara***, Tadaharu \\ NAKamura**** and KOHHEI TANAKA** \\ ** Department of Mineral Industry, School of Science and Engineering, Waseda University \\ *** Department of Geology and Mineralogy, Faculty of Science, Niigata University \\ **** Institute of Earth Science, Faculty of Science, School of Education, Waseda University
}

\section{INTRODUCTION}

Xonotlite $\left[\mathrm{Ca}_{3}\left(\mathrm{Si}_{3} \mathrm{O}_{8}\right)(\mathrm{OH})_{2}\right.$, Berman, 1937; $\mathrm{Ca}_{5}\left(\mathrm{Si}_{5} \mathrm{O}_{14}\right)(\mathrm{OH})_{2}$, Taylor, 1954, Pistorius, $1963 ; \mathrm{Ca}_{6}\left(\mathrm{Si}_{6} \mathrm{O}_{17}\right)(\mathrm{OH})_{2}$, Mamedov and Belov, 1955, 1956, Dent and Taylor, 1956], a kind of hydrated calcium silicates, is a familiar substance which may be prepared synthetically in the system $\mathrm{CaO}-\mathrm{SiO}_{2}-\mathrm{H}_{2} \mathrm{O}$ over a considerably wide temperature and pressure range (Buckner et al., 1960; Pistorius, 1963). As is well known, this substance is manufactured as building materials and thermal insulators and is commonly recognized in the products of cement reaction at relatively lower temperatures. Whilist, Taylor (1959) revealed that hydrothermal treatment of tobermorite with layer structure $\left[\mathrm{Ca}_{5}\left(\mathrm{Si}_{6} \mathrm{O}_{16}\right)(\mathrm{OH})_{2} \cdot 4 \mathrm{H}_{2} \mathrm{O}\right.$, Megaw and Kelsey, 1956; Taylor and Howison, 1957] at $380^{\circ} \mathrm{C}$ and 250 atm. water vapour pressure converts this mineral into xonotlite. However, it is a rare mineral in nature, and only several occurrences have so far been reported.

Xonotlite was discovered at Tetela de Xonotla, State of Puebla, Mexico by Rammelsberg in 1866 (the original spelling was "xonaltit") (Dana, 1909). Since then, the additional occurrences of this mineral from California, New Jersey, Scotland, etc. have been recorded, and its mineralogical studies have been undertaken by some investigators. The "unit-cell" or "pseudo-cell" dimensions of xonotlite were given for the first time by Berman (1937), and lately its structural model and the celldimensions were proposed by Mamedov and Belov (1955, 1956); subsequently the similar characteristics of xonotlite from San Francisco were given by Dent and Taylor (1956), and they are summarized as follows; monoclinic cell with $\mathrm{a}_{0}=16.95 \AA, \mathrm{b}_{0}=7.33 \AA, \mathrm{c}_{0}=7.03 \AA, \beta=90^{\circ}$.

On the other hand, jurupaite $\left[(\mathrm{Ca}, \mathrm{Mg})_{2}\right.$ $\left(\mathrm{Si}_{2} \mathrm{O}_{5}\right)(\mathrm{OH})_{2}$, Eakle, 1921], a hydrated calcium silicate containing magnesium, in which the molecular ratio of lime to magnesia being nearly 7:1 (Eakle, 1921), was reexamined together with xonotlite by Taylor (1954), and it was revealed that jurupaite and xonotlite are isostructural compounds, namely, in jurupaite calcium is partly replaced by magnesium. In spite of accumulation of literature on xonotlite and jurupaite, there remain some doubts regard-

(Manuscript received, Nov, 18, 1971)

* Presented at the Annual Meeting of the Geological Society of Japan, held in Nagoya, on Oct. 11, 1967 (Otsuka et al., 1968). 
ing the ideal formula in relation to water content and some problems on polytypism and polymorphism of the crystals; and their space group is still undetermined.

In Japan, the first occurrence of xonotlite associated with jadeite-bearing albitite from the Kotaki Village, Niigata Prefecture was reported by Ohmori (1939). However, it was identified optically and the additional works in more detail have not appeared.

The occurrence of jadeite associated with albitite from the Ohmi-Kotaki district, Niigata Prefecture was described by Kawano (1939) and Ohmori (1939), and the additional works have been conducted by Iwao (1953) and Chihara (1958, 1960, 1970, 1971). During the intensive mineralogical studies on several specimens of white fibrous minerals associated with jadeite-bearing albitite from "the Hisui dani" (Jade valley), Hashidate, the Ohmi district, and they had been taken by $T$. Imayoshi of the National Science Museum; the only one specimen was revealed to be xonotlite and the remainders pectolite (Otsuka et al., 1968). The present study was undertaken to offer some mineralogical data for the xnonotlite and to give a brief discussion on the problems regarding the genesis of the mineral. Optical, X-ray diffraction, chemical, thermal and infrared absorption methods have been employed in this study. This work was planned and partly carried out at the Department of Geology and Mineralogy, Niigata University, and continued at the Department of Mineral Industry, Waseda University. The results of a mineralogical study on the pectolite will be reported separately in another paper by the present writers. The manuscript of this paper was prepared by the first writer (N.I.).

\section{Location and Geologic SetTing}

The Ohmi district occupies the southwestern border of Niigata Prefecture. Itoigawa City, approximately at Lat. $37^{\circ}$ $02^{\prime} \mathrm{N}$, Long. $137^{\circ} 51^{\prime} \mathrm{E}$, lies in the north of the district. As shown in Fig. 1, "the Hisui-dani"' where many boulders of albitite

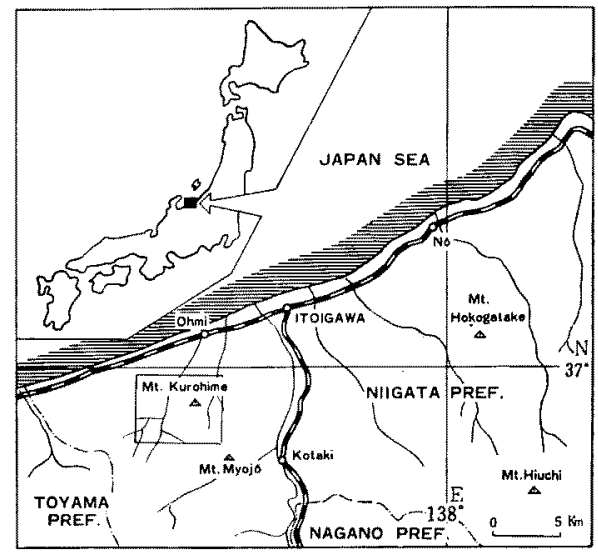

Fig. 1. Map showing the location of the Ohmi district.

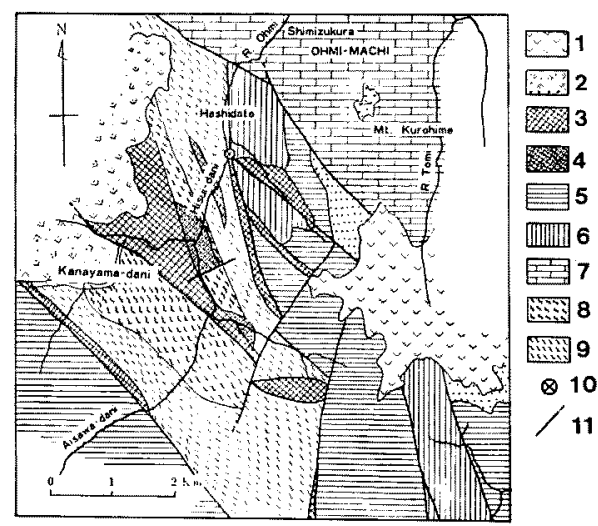

Fig. 2. Geological map along "the Hisuidani" and its environs, showing the locality of the xonotlite.

1: Neogene volcanic rocks, 2: Tertiary sediments, 3: Serpentinite, 4: Meta-gabbro $\sim$ Diabase, 5: The Kuruma Group, 6: Palaeozoic clayslate, graywacke-sandstone, schalstein etc. 7: Palaeozoic limestone, 8: Crystalline schist (biotite zone), 9: Ditto (chlorite zone), 10: Locality of the xonotlitebearing albitite, 11: Fault. 
containing occasionally jadeite, with small amounts of xonotlite, pectolite, natrolite, etc. are found on either sides of the stream and on the floor, is located at about $10 \mathrm{~km}$ southwest of Itoigawa City.

As shown in Fig. 2 , the geologic structure of the mapped area is complicated by many faults and faulted block structure prevails, however, a glance at the map indicates that the geologic units may be divided broadly into the following five; 1) metamorphic rocks, 2) nonmetamorphic Palaeozoic rocks, 3) Meosozoic rocks (Kuruma Group), 4) serpentinite and gabbroic rocks, and 5) Tertiary sediments.

From a geotectonic viewpoint, the district is on the immediately southwestern side of "Fossa Magna" and is the northeastern extremity of the Sangun metamorphic terrain. In terms of the mineral facies concept, the metamorphic rocks are referred to the glaucophane-schist facies and the epidote-amphibolite facies (Banno, 1958). As seen in Fig. 2, the chlorite zone (glaucophane-schist facies) and the biotite zone (epidote-amphibolite facies) are discriminated in the schists of the mapped area.

The non-metamorphic Palaeozoic Complex in the district is mainly composed of graywacke-sandstore, slate, schalstein, chert and limestone, and is characterized by the intercalation of the thick limestone formatiors. According to the fossile evidence in limestone, the Palaeozoic Complex in the district has been believed to range frcm early Carboniferous to middle Permian in age (Kawada, 1954).

The Kurura Group crops out on the southeastern and southwestern mountainous area of the district, overlying unconformably the non-metamorphic Palaeozoic rocks.
It consists largely of shale, sandstone and conglomerate. Thin seams of coal are intervened at some horizons. From the fossile evidence, this group is considered to be early Jurassic in age.

During the period of orogenic movements, probably in late Mesozoic Era, serpentinite and gabbroic rocks have intruded along the faults which define the boundaries between the metamorphic rocks and Mesozoic rocks and/or non-metamorphic Palaeozoic rocks. In other words, this district is part of the northeast-trending "serpentine belt", being aligned along the tectonic line. However, the longer dimensions of individual of the ultrabasic and basic intrusives are controlled by the trends of faults, and they have an elongation in the directions ranging from NNW-SSE to E-W.

The Tertiary system, some of which contains pyroclastic rocks of rhyolitic composition and in some places rhyolitic lava rests unconformably on the above-mentioned older rocks with basal conglomerate.

\section{Mode OF OCGURRENCE}

The occurrence of jadeite in Japan had not been krown untill its first occurrence from the Kotaki Village was reported by Kawano (1939) and Ohmori (1939). However, at that time, its mode of occurrence in detail was rot clear. Subsequently, Iwao (1953) conducted the intensive field works and petrography on the jadeite-bearing albitite in the Kotaki area and clarified that some of them occur as being enclosed in serpentinite as spherical masses and the most typical mode of occurrence of the jadeite is represented by concentric spherical mineral zoning in the order of albitite $\rightarrow$ white jadeite $\rightarrow$ green jadeite $\rightarrow$ actinolite $\rightarrow$ host serpentinite from inner to outer. Recently, Chihara (1960, 1970, 1971) also 
described the similar mineralogical sequence in the rocks of the district.

The xonotlite now under investigation was found in a boulder of albitite on the floor of "the Hisui-dani", so that the direct field relationship between the albitite and the surrounding rocks is unknown, but it was observed that the xonotlite occurs as narrow veins, $\mathbf{3}-\mathbf{5} \mathrm{cm}$ in width, and the veins traverse the host albitite, indicating that the mineral represents the products in the latest stage of crystallization (Imayoshi's comments).

Judging from the geological features of the mapped area as shown in Fig. 2, and from the mode of occurrence of jadeitebearing albitite in the district as revealed by previous workers, it may be no doubts that the albitite boulder in question was enclosed with serpentinite in its initial position.

\section{DESGRIPTION OF SPEGIMEN}

In hand specimen, the present xonotlite is seen to consist of the fibrous aggregates as shown in Fig. 3. The maximum length of the fibers attains to $1 \mathrm{~cm}$, and the colour is pale-pinkish white with somewhat silky luster. The mineral dissolved in dilute hydrochloric acid leaving residue of silica

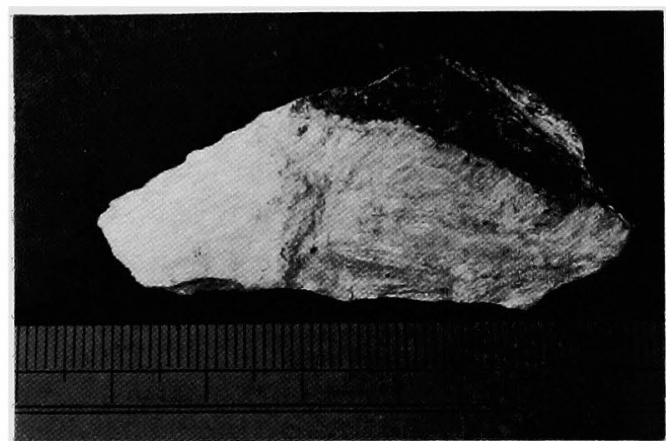

Fig. 3. Photograph of the hand specimen of the xonotlite used in the present study.

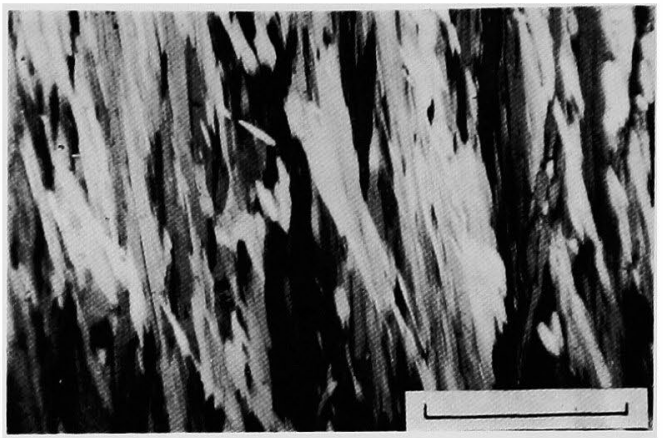

Fig. 4. Photomicrograph of the xonotlite from Hashidate. The scale indicates $1 \mathrm{~mm}$. Crossed nicols.

without gelatinization and qualitative microchemical test indicated the abundance of calcium.

As shown in Fig. 4, under the microscope, the mineral is seen to be entirely composed of the aggregates of laths or fibers of xonotlite, and sometimes in approximately parallel orientation, showing parallel extinction and positive elongation. The length of lath or fiber is usually $1 \mathrm{~mm}$ or less.

\section{Optical Properties}

The three principal refractive indices of the present xonotlite were measured by the dispersion method, using immersion media and a Carl Zeiss monochromator with grating optics at constant temperature of $25^{\circ} \mathrm{C} \quad\left( \pm 1^{\circ} \mathrm{C}\right)$. The determination of optical orientation and the optical angle (2V) measurement were made with a Leitz four axes universal stage using white light.

In his study on the optical properties of jadeite and the associated minerals from the Kotaki Village, Ohmori (1939) assumed that the principal cleavage of xonotlite is parallel to (010). In the present optical study, however, the principal cleavage of xonotlite was taken as (100) and the second one as (001) after Dent and Taylor (1956). 
The results thus obtained are summarized below. Refractive indices: $\alpha_{\mathrm{D}}=$ 1.584, $\beta_{\mathrm{D}}=1.586, \gamma_{\mathrm{D}}=1.594$ (all \pm 0.001 ), $\gamma_{D^{-}} \alpha_{D}=0.010$. Colourless in thin section. It is optically positive with $2 \mathrm{~V}$ over $\mathrm{Z}=$ very low, $26^{\circ} 24^{\prime}$ (cal.). Optical orientation: $\mathrm{a}=\mathrm{X}, \mathrm{b}=\mathrm{Z}, \mathrm{c}=\mathrm{Y}$, optical plane is parallel to (001).

From the description as noted above, it is found that the optical properties of the present material do not depart considerably from those of xonotlites in literature, except for the difference in optical orientation due to the above-mentioned different assumption.

\section{X-Ray Diffragtion Data}

The X-ray diffraction studies of the present xonotlite were conducted in the following two different ways; 1) recording of X-ray diffraction patterns of the material, both natural and heated with $\mathrm{X}$-ray diffractometer, and 2) precision determination of the cell dimensions with $\mathrm{X}$-ray diffractometer using an internal standard.

The X-ray diffraction patterns for the material, both natural and heated at $900^{\circ} \mathrm{C}$,

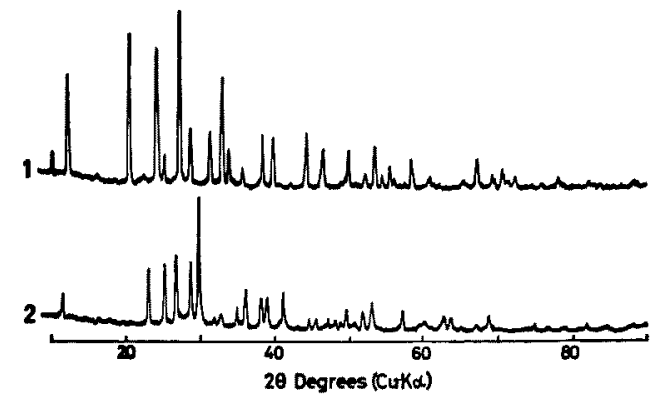

Fig. 5. X-ray diffraction patterns of the xonotlite from Hashidate, both natural and the heated equivalent. 1: At room temperature, 2: Heated to $900^{\circ} \mathrm{C}$
Table 1. X-ray powder diffraction data for xonotlites.

\begin{tabular}{|c|c|c|c|c|}
\hline \multicolumn{2}{|c|}{ (1) } & \multicolumn{3}{|c|}{ (2) } \\
\hline $\begin{array}{c}d \\
\text { (obs.) }\end{array}$ & $\begin{array}{c}I \\
\text { (obs.) }\end{array}$ & $\stackrel{d}{d}$ & $\begin{array}{c}I \\
\text { (obs.) }\end{array}$ & $h k l$ \\
\hline 8.58 & 10 & 8.5 & 20 & 200 \\
\hline 7.02 & 45 & 7.05 & 40 & 001 \\
\hline 4.25 & 65 & 4.27 & 40 & 400 \\
\hline 3.93 & 2 & 3.90 & 20 & h1l \\
\hline 3.63 & 60 & 3.65 & 70 & 401 \\
\hline 3.50 & 10 & & & \\
\hline 3.24 & 100 & 3.23 & 70 & $\left\{\begin{array}{l}202 \\
121\end{array}\right.$ \\
\hline 3.08 & 25 & 3.07 & 100 & 320 \\
\hline 2.84 & 25 & 2.83 & 50 & 321 \\
\hline 2.70 & 45 & 2.71 & 40 & 402 \\
\hline 2.63 & 15 & 2.65 & 20 & h1l \\
\hline 2.51 & 10 & 2.51 & 40 & 122 \\
\hline 2.34 & 20 & 2.34 & 30 & 003 \\
\hline 2.25 & 20 & 2.25 & 30 & 203 \\
\hline 2.04 & 20 & 2.04 & 85 & $\left\{\begin{array}{l}801 \\
522\end{array}\right.$ \\
\hline 1.95 & 15 & 1.95 & 85 & 721 \\
\hline 1.82 & 15 & 1.84 & 40 & 040 \\
\hline 1.745 & 2 & 1.756 & 30 & \\
\hline 1.711 & 15 & 1.710 & 40 & \\
\hline 1.682 & 2 & 1.687 & 20 & \\
\hline 1.652 & 10 & 1.655 & 20 & \\
\hline 1.638 & 2 & 1.639 & 20 & \\
\hline 1.604 & 2 & 1.598 & 10 & \\
\hline 1.576 & 10 & 1.575 & 20 & \\
\hline 1.522 & 2 & 1.519 & 30 & \\
\hline 1.428 & 2 & 1.427 & 20 & \\
\hline 1.392 & 10 & 1.393 & 20 & \\
\hline 1.348 & 2 & 1.348 & 10 & \\
\hline 1.318 & 2 & 1.319 & 10 & \\
\hline 1.306 & 2 & 1.306 & 20 & \\
\hline 1.252 & 2 & 1.262 & 10 & \\
\hline 1.224 & 2 & 1.22 & $10 \mathrm{br}$ & \\
\hline 1.198 & 1 & 1.200 & 10 & \\
\hline 1.174 & 1 & & & \\
\hline 1.124 & 1 & 1.125 & 10 & \\
\hline 1.109 & 1 & 1.106 & 20 & \\
\hline 1.103 & 1 & & & \\
\hline 1.090 & 1 & & & \\
\hline
\end{tabular}

(1) Xonotlite from Hashidate, the Ohmi district, Niigata Pref.

(2) Xonotlite from Tetela de Xonotla (ASTM Card no. 10-488)

The $d$-spacings are given in $A$ unit. br: Broad reflection. 
were obtained with a "Geigerflex" X-ray diffractometer using Ni-filtered $\mathrm{CuK} \alpha$ radiation $(\lambda=1.5418 \AA)$. Instrument settings in all runs were; voltage: $30 \mathrm{kV}$, current: $15 \mathrm{~mA}$, divergence slit: $1^{\circ}$, scatter slit: $1^{\circ}$, receiving slit: $0.2 \mathrm{~mm}$, scanning speed: $1^{\circ}$ per minute, chart speed: $1 \mathrm{~cm}$ per minute, scale factor: 16 , time const.: 2 sec., detector: G.C.

The X-ray diffraction patterns for the materials thus obtained are shown in Fig. 5. Also, the observed powder data on the material at room temperature and those for xonotlite from Tetela de Xonotla are compared in Table 1, and those for the heated equivalent at $900^{\circ} \mathrm{C}$ are compared with those for $\beta$-wollastonite from Chiapas, Mexico in Table 2. Where, the term $\beta$ wollastonite is used to include wollastonite (triclinic), parawollastonite (monoclinic) and intergrowth of the two. Table 1 shows that the observed $d$-spacings of the present xonotlite are in good agreement with those on the material from Tetela de Xonotla, however, there is some discrepancy between the intesities of reflections of the two, probably due to the preferred orientation of the powder in the present experiment. Table 2 indicates that the powder data for the heated equivalent at $900^{\circ} \mathrm{C}$ are in good agreement with those for $\beta$-wollastonite from Chiapas, Mexico in both observed $d$ spacings and intensities.

For the purpose of precision determination of the cell dimensions, an attempt was made to take the $b$-axis (fiber axis)

Table 2. X-ray powder diffraction data for $\beta$-wollastonites.

(1) The material heated to $900^{\circ} \mathrm{C}$ of the xonotlite from Hashidate, the Ohmi district, Niigata Pref.

(2) The $\beta$-wollastonite from Chiapas, Mexico (ASTM Card no. 10-487).

The $d$-spacings are given in $\dot{A}$ unit. br: Broad reflection.
Table 2. X-ray powder diffraction data for $\beta$-wollastonites.

\begin{tabular}{|c|c|c|c|c|}
\hline \multicolumn{2}{|c|}{$(1)$} & \multicolumn{3}{|c|}{$(2)$} \\
\hline $\begin{array}{c}d \\
\text { (obs.) }\end{array}$ & $\begin{array}{c}I \\
(\mathrm{obs} .)\end{array}$ & $\begin{array}{c}d \\
\text { (obs.) }\end{array}$ & $\begin{array}{c}I \\
\text { (obs.) }\end{array}$ & $h k l$ \\
\hline \multirow[t]{2}{*}{7.7} & \multirow[t]{2}{*}{30} & 7.7 & 40 & 200 \\
\hline & & 4.05 & 10 & h1l \\
\hline 3.84 & 45 & 3.83 & 80 & 400 \\
\hline \multirow[t]{2}{*}{3.53} & \multirow[t]{2}{*}{50} & 3.52 & 80 & 002 \\
\hline & & 3.40 & 5 & h1e \\
\hline \multirow[t]{2}{*}{3.32} & \multirow[t]{2}{*}{60} & 3.31 & 80 & 202 \\
\hline & & 3.16 & 5 & $11 \overline{1}$ \\
\hline 3.10 & 50 & 3.09 & 30 & 202 \\
\hline 2.98 & 100 & 2.97 & 100 & 310 \\
\hline 2.80 & 10 & 2.80 & $10 \mathrm{br}$ & $31 \overline{1}$ \\
\hline 2.72 & 10 & 2.72 & 10 & $40 \overline{2}$ \\
\hline 2.56 & 20 & 2.55 & 30 & $\left\{\begin{array}{l}11 \overline{2} \\
600\end{array}\right.$ \\
\hline 2.48 & 30 & 2.47 & 60 & $\left\{\begin{array}{l}112 \\
402\end{array}\right.$ \\
\hline 2.35 & 25 & 2.33 & 40 & $\left\{\begin{array}{l}003 \\
510 \\
31 \overline{2}\end{array}\right.$ \\
\hline \multirow[t]{2}{*}{2.30} & \multirow[t]{2}{*}{25} & \multirow[t]{2}{*}{2.29} & \multirow[t]{2}{*}{40} & $\left\{\begin{array}{l}601 \\
20 \overline{3}\end{array}\right.$ \\
\hline & & & & $\left\{\begin{array}{l}602 \\
312\end{array}\right.$ \\
\hline 2.18 & 30 & 2.18 & 60 & $\left\{\begin{array}{l}512 \\
511\end{array}\right.$ \\
\hline 2.09 & 5 & 2.08 & 5 & $40 \overline{3}$ \\
\hline 2.02 & 10 & 2.01 & 20 & $51 \overline{2}$ \\
\hline 1.98 & 10 & 1.98 & 20 & 602 \\
\hline 1.92 & 10 & 1.91 & 20 & 800 \\
\hline 1.88 & 10 & 1.88 & .20 & - \\
\hline 1.86 & 10 & 1.86 & 10 & 020 \\
\hline 1.83 & 15 & 1.83 & 60 & \\
\hline 1.81 & 5 & 1.80 & 5 & \\
\hline 1.799 & 5 & 1.79 & 5 & \\
\hline 1.760 & 15 & 1.75 & 40 & \\
\hline 1.723 & 30 & 1.72 & 60 & \\
\hline 1.607 & 15 & 1.602 & 40 & \\
\hline 1.538 & 10 & 1.531 & 10 & \\
\hline 1.517 & 5 & 1.515 & 5 & \\
\hline 1.480 & 10 & 1.478 & $20 \mathrm{br}$ & \\
\hline 1.459 & 10 & 1.455 & 30 & \\
\hline 1.423 & 2 & 1.426 & 5 & \\
\hline 1.394 & 2 & 1.387 & 5 & \\
\hline \multirow[t]{3}{*}{1.362} & \multirow[t]{3}{*}{10} & 1.358 & 30 & \\
\hline & & 1.332 & 10 & \\
\hline & & 1.312 & 5 & \\
\hline 1.267 & 5 & & & \\
\hline 1.240 & 2 & & & \\
\hline
\end{tabular}


rotation photographs of the fine fiber of the mineral with calibrated micro Debye-Scherrer camera of $28.6 \mathrm{~mm}$ diamețer in conjunction with microfocus X-ray generator (Microflex, model B-3) made by Rigaku Denki Co., Japan, but it was unsuccessful because of the difficulty to obtain a single fiber. Since the fiber photographs revealed that the fiber consists of very small crystals, having their needle axes which are nearly parallel but oriented at somewhat random with respect to the fiber axis. Accordingly, the determination was made by the internal standard method using a "Geigerflex" Xray diffractometer connected with a highpower Rota Unit. The material used as an internal standard was $\alpha$-alumina, the $d$ spacings on reflections of which were calibrated by extra-pure silicon $\left(\mathrm{a}_{0}=\mathbf{5 . 4 3 0 6 _ { 2 }}\right.$ $\dot{\mathrm{A}}$ at $25^{\circ} \mathrm{C}$ ). The $d$-spacings on 400,003 , 040 and 801 reflections of the present xonotlite were carefully measured in the following manner. The midpoint along the $2 \theta$-coordinate at the half height from the background radiation level of the intensity profile of a given reflection on the diffractometer chart was drawn vertically down to the degree-marking line, where $2 \theta$ value was measured. Since the $d$-spacings of $a$ alumina calibrated by extra-pure silicon have a high precision, the position of the xonotlite reflections can be corrected for instrumental errors. The 018, 208, 311 and 318 reflections of $\alpha$-alumina were chosen in order to bracket the xonotlite reflections under consideration. The corrections were plotted against $2 \theta$ values and finally interpolated corrections were applied to the xonotlite reflections. The $d$-spacings were determined from graphs based upon the data given by Switzer et al. (1948).

Instrument settings in all runs were; unfiltered $\operatorname{Cr} \alpha \beta$-radiation $\left(\mathrm{CrK} a_{1}=2.28962\right.$
Table 3. Cell dimensions of xonotlites and jurupatie.

\begin{tabular}{c|c|c|c|c|c}
\hline & \multicolumn{1}{c|}{$(1)$} & \multicolumn{1}{c|}{$(2)$} & \multicolumn{1}{c|}{$(3)$} & \multicolumn{1}{c|}{$(4)$} & \multicolumn{1}{c}{$(5)$} \\
\hline $\mathbf{a}_{0}{ }^{*}$ & $17.05 \AA$ & $16.95 \AA$ & $8.50 \AA$ & $8.55 \AA$ & $8.50 \AA$ \\
$\mathbf{b}_{0}$ & 7.36 & 7.33 & 7.32 & 7.34 & 7.32 \\
$\mathbf{c}_{0}$ & 7.01 & 7.03 & 7.05 & 7.03 & 7.05 \\
$\beta$ & $\cong 90^{\circ}$ & $\cong 90^{\circ}$ & $90^{\circ} \pm 1^{\circ}$ & $\cong 90^{\circ}$ & $90^{\circ} \pm 1^{\circ}$ \\
\hline
\end{tabular}

(1) Xontlite from Hashidate, the Ohmin district, obtained from the data of internal standard method using X-ray diffractometer (the present writers, 1972).

(2) Xonotlite from Army Street, San Fransisco (Dent and Taylor, 1956).

(3) Xonotlite from Tetela de Xonotla, Mexico (Taylor, 1954).

(4) Xonotlite from Franklin (Berman, 1937).

(5) Jurupaite from Crestmore, California (Taylor, 1954).

* $a_{0}$ is a variable integral multiple of $8.50 \AA$.

$\left.\AA, \quad \mathrm{K} \alpha_{2}=2.29352 \AA, \quad \mathrm{K} \beta_{1}=2.08479 \AA\right)$, voltage: $50 \mathrm{kV}$, current: $30 \mathrm{~mA}$, divergence slit: $1^{\circ}$, scatter slit: $1^{\circ}$, receiving slit: 0.3 $\mathrm{mm}$, time const.: $4 \mathrm{sec}$, scanning speed: $0.25^{\circ}$ per minute, chart speed: $2 \mathrm{~cm}$ per minute, count full scale: 800,1000 and 2000 cps, detector: S.C..

The results gave; $\mathrm{d}_{400}=4.261 \AA \mathrm{d}_{040}=$ $1.839 \AA, \mathrm{d}_{003} \cong 2.336 \AA$ and $\mathrm{d}_{\mathbf{8 0 1}}=2.040 \AA$. The calculation from the above results led to the following values for the dimensions of monoclinic cell; $a_{0}=17.05 \AA, b_{0}=7.36 \AA$, $c_{0}=7.01 \AA, \quad \beta \cong 90^{\circ}$. In Table 3 , the values are compared with those already given in previous papers, and it is noted that there is no remarkable departure among them. As pointed out by Dent and Taylor (1956) and Gard (1966), the above monoclinic cell indicates merely a "pseudocell".

\section{Chemical Compostion}

The material used for chemical analysis was carefully selected from the fibrous aggregates of xonotlite as being free from impurities as possible under the binocular 
Table 4. Chemical compositions of xonotlites and jurupaite.

\begin{tabular}{|c|c|c|c|c|c|c|}
\hline & (1) & (2) & (3) & (4) & (5) & (6) \\
\hline $\mathrm{SiO}_{2}$ & 50.68 & 49.58 & 50.17 & 48.87 & 50.17 & 50.42 \\
\hline $\mathrm{Al}_{2} \mathrm{O}_{3}$ & 0.05 & & & & & \\
\hline $\mathrm{Fe}_{2} \mathrm{O}_{3}$ & 0.05 & & 1.04 & & & \\
\hline $\mathrm{FeO}$ & 0.04 & 1.31 & & & & \\
\hline $\mathrm{MnO}$ & & 1.79 & & & & \\
\hline $\mathrm{MgO}$ & tr. & & tr. & 4.19 & & \\
\hline $\mathrm{CaO}$ & 46.02 & 43.56 & 45.45 & 38.66 & 46.82 & 47.06 \\
\hline $\mathrm{Na}_{2} \mathrm{O}$ & 0.03 & & & & & \\
\hline $\mathrm{K}_{2} \mathrm{O}$ & tr. & & & & & \\
\hline $\mathrm{H}_{2} \mathrm{O}(+)$ & 2.96 & 370 & 318 & 789 & 3.01 & 2.52 \\
\hline $\mathrm{H}_{2} \mathrm{O}(-)$ & 0.22 & 3.60 & 3.18 & 7.89 & & \\
\hline Total & 100.05 & 99.94 & 99.84 & 99.61 & 100.00 & 100.00 \\
\hline
\end{tabular}

(1) Xonotlite from Hashidate, the Ohmi district, Analyst: T. Nakamura (the present writers, 1968).

(2) White xonotlite from Tetela de Xonotla, Mexico (Rammelsberg, 1886).

(3) Xonotlite from Santa Inez, California (Larsen,1917).

(4) Jurupaite from Crestmore, California (Eakle, 1921).

(5) Theoretical value of xonotlite on the basis of the formula $\mathrm{Ca}_{5}\left(\mathrm{Si}_{5} \mathrm{O}_{14}\right)(\mathrm{OH})_{2}($ Taylor, 1955 ; Pistorius, 1963).

(6) Theoretical value of xonotlite on the basis of the formula $\mathrm{Ca}_{6}\left(\mathrm{Si}_{8} \mathrm{O}_{17}\right)(\mathrm{OH})_{2}$ (Mamedov and Belov, 1955, 1956).

microscope, and then it was examined both optically and with an aid of X-ray diffraction patterns. The chemical analysis of the material (about $2.5 \mathrm{~g}$ ) thus obtained was performed by the fourth writer (T.N.), using ordinary wet method. An attempt was made to determine the content of $\mathrm{H}_{2} \mathrm{O}(+)$ by use of Penfield tube, but it was not so successful because of the dehydroxylation of the mineral at higher temperatures. Accordingly, the material was first dried to constant weight at $105^{\circ} \mathrm{C}\left( \pm 5^{\circ} \mathrm{C}\right)$ and then ignited to about $900^{\circ} \mathrm{C}$. The weight loss thus obtained was assumed to be the loss of $\mathrm{H}_{2} \mathrm{O}(+)$. No deduction of weight increase upon heating due to the oxidation of ferrous iron was made, because of its negligible amounts.

The results of an analysis are listed in Table 4, together with those of some specimens including jurupaite already appeared in previous papers. As shown in this table, the results of an analysis are in general agreement with those of xonotlites reported hitherto. Based upon 19 oxygen atoms contained in the ideal formula $\mathrm{Ca}_{6} \quad\left(\mathrm{Si}_{6} \mathrm{O}_{17}\right)(\mathrm{OH})_{2}$ (Mamedov and Belov, $1965,1966)$, the following structural formula was computed from the analysis; $\mathrm{Ca}_{5.83}$

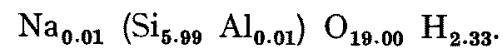

\section{Thermal Data}

The thermal studies of the present xonotlite were carried out by use of a "Simultaneous Thermobalance Analyzer" made by Rigaku Denki Co., Japan (Saito et al., 1964). This is an apparatus for simultaneous recording of thermogravimetric (TG) curve, derivative thermogravimetric (DTG) curve and differential thermal analysis (DTA) curve ("Thermograph"). Instrument settings in a run were; TG sensitivity: $50 \mathrm{mg}$ in full scale, DTG sensitivity: $10 \mathrm{mg}$ per minute in full scale, DTA 


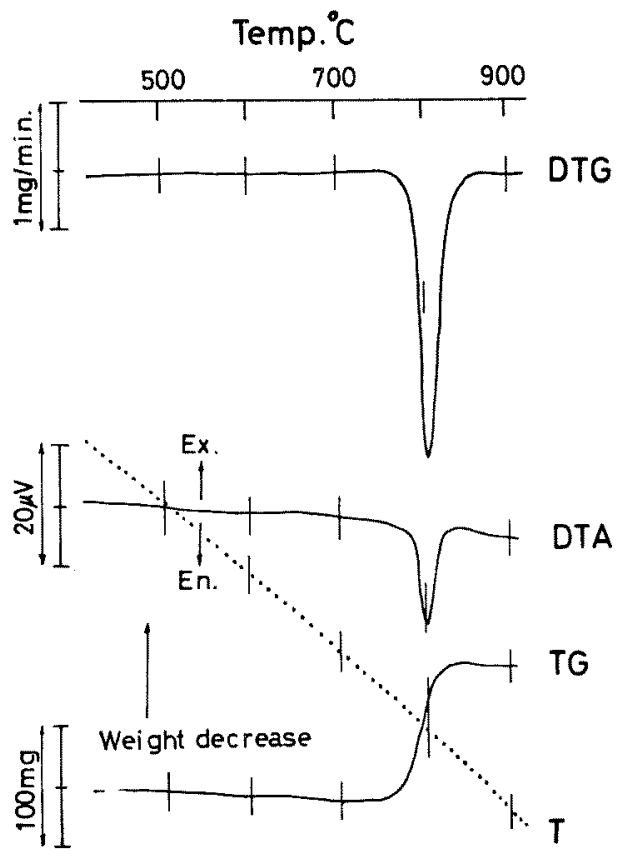

Fig. 6. Thermograph of the xonotlite from Hashidate.

sensitivity: $100 \mu \mathrm{V}$ in full scale, heating rate: $5^{\circ} \mathrm{C}$ per minute, chart speed: $120 \mathrm{~mm}$ per hour, temperature-indicating thermocouple: Pt-Pt.Rh (13 per cent), differential thermocouple : Pt-Pt.Rh (13 per cent)-Pt. The weight of the sample (-200 mesh) charged in a cap was $479 \mathrm{mg}$.

The thermograph of the material is shown in Fig. 6. As seen from the $\mathrm{TG}$ and DTG curves in the figure, the weight loss due to dehydroxylation of the mineral accompanied by structural change involving the conversion into $\beta$-wollastonite proceeds rapidly in a narrow temperature range from $780^{\circ}$ to $850^{\circ} \mathrm{C}$. Dent and Taylor (1956) showed that at $775^{\circ}-800^{\circ} \mathrm{C}$ xonotlite changes to $\beta$-wollastonite at atomospheric humidity. The maximum rate of weight loss reaches $3 \mathrm{mg}$ per minute ( 0.01 per cent per minute) at $810^{\circ} \mathrm{C}$. The DTA curve is very similar to the DTG curve, and is characterized by the sharp and strong endothermic peak with symmetrical shape at $800^{\circ} \mathrm{C}$.

\section{INFrared Absorption Spectra}

The infrared absorption spectra of the

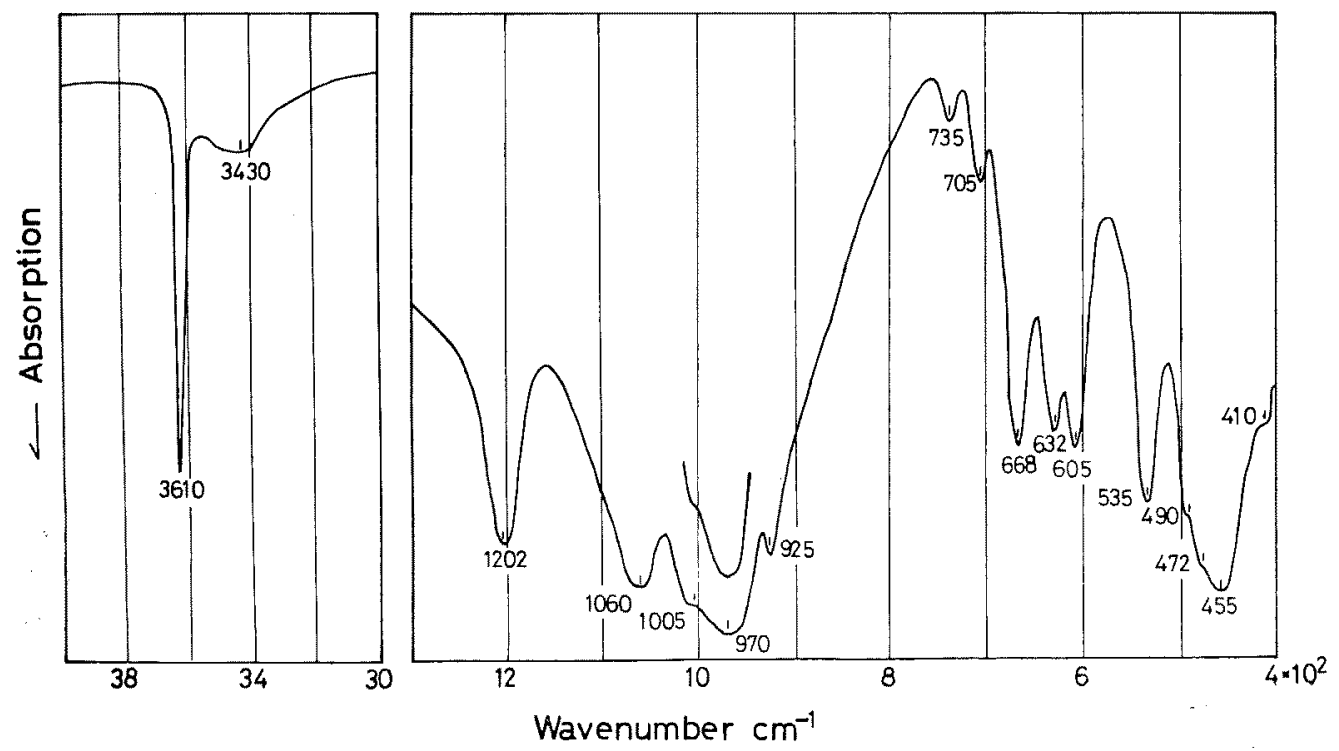

Fig. 7. Infrared absorption spectra of the xonotlite from Hashidate, 
present xonotlite were recorded with a Hitachi infrared spectrometer with grating optics (model EPI-G2). In the measurement of the spectrum ranging from 1300 to $400 \mathrm{~cm}^{-1}, \mathrm{KBr}$ tablet method was employed. However, the spectrum of the $\mathrm{OH}$ region from 4000 to $3600 \mathrm{~cm}^{-1}$ was obtained by the paste method using Nujol as a base in order to avoid the effect of sorption of water.

As shown in Fig. 7, in the OH-region, the absorption due to $\mathrm{OH}$-stretching vibration appears as a very sharp band at $3610 \mathrm{~cm}^{-1}$, and a broad band at $3430 \mathrm{~cm}^{-1}$. In the region from 1300 to $800 \mathrm{~cm}^{-1}$, there is a sharp and strong band at $1202 \mathrm{~cm}^{-1}$, and absorption due to $\mathrm{Si}-\mathrm{O}$ vibration appears as a broad band ranging from 1100 to $900 \mathrm{~cm}^{-1}$, having absorption peaks at $1060,1005,970$ and $925 \mathrm{~cm}^{-1}$. In the lower frequency region from 800 to 400 $\mathrm{cm}^{-1}$, which corresponds to that of lattice vibration, there are many absorption bands, although the assignment of these bands is not clear at the present state of the writers' knowledge. Namely, a strong tripple at 668,632 and $605 \mathrm{~cm}^{-1}$ with shoulders at 735 and $705 \mathrm{~cm}^{-1}$, sharp and strong band at $535 \mathrm{~cm}^{-1}$ and a broad but strong band at $455 \mathrm{~cm}^{-1}$ with shoulders at 490,472 and $410 \mathrm{~cm}^{-1}$ are recognzied.

\section{Discussion, Conclusions AND Related Problems}

Summarizing the data noted previously, it may be concluded that the mineral now under investigation is identical with xonotlite in all mineralogical properties. However, as pointed out in the preceding section, there remain some doubts regarding the ideal formula for xonotlite and some problems on its polymorphism and polytypism of the crystal. Berman (1937) pointed out that ideal formula for xonotlite must be $\mathrm{Ca}_{3}\left(\mathrm{Si}_{3} \mathrm{O}_{8}\right)(\mathrm{OH})_{2}$ on the basis of its cell dimensions and density. If this formula is used, water content is 4.91 per cent. Subsequently, Taylor (1954) has described that in the light of the data of chemical analyses of xonotlites, water contents are usually lower than the values as expected from Berman's formula and the formula $\mathrm{Ca}_{5}\left(\mathrm{Si}_{5} \mathrm{O}_{14}\right)(\mathrm{OH})_{2}$ seems to be compatible.

Recently, Mamedov and Belov (1955, 1956) have established a structural model of xonotlite comprising $\left(\mathrm{Si}_{6} \mathrm{O}_{17}\right) \infty$ double chain and the tripple rows of calcium atoms parallel to $b$-axis. The corresponding cell formula may be written as; $\mathrm{Ca}_{6}\left(\mathrm{Si}_{6} \mathrm{O}_{17}\right)$ $(\mathrm{OH})_{2}, Z=2$ in a "pseudo-cell". In the case of the present xonotlite, however, the chemical composition is compatible with Taylor's formula $\mathrm{Ca}_{5}\left(\mathrm{Si}_{5} \mathrm{O}_{14}\right)(\mathrm{OH})_{2}$ rather than Mamedov's one, since the structural formula which was computed on the basis of 16 oxygen atoms contained in the above Taylor's formula may be given as; $\mathrm{Ca}_{4.91}$ $\begin{array}{lllll}\mathrm{Na}_{\mathbf{0 . 0 1}} & \left(\mathrm{Si}_{6.04}\right. & \mathrm{Al}_{0.01} & \mathrm{O}_{16.00} & \mathrm{H}_{1.97} \\ .\end{array}$

In his studies on the thermal decomposition of portlandite and xonotlite to high temperatures and pressures, Pistorius (1963) already suggested that a new highpressure phase which appears in the highpressures and low-temperatures field of his phase diagram in the ternary system $\mathrm{CaO}-\mathrm{SiO}_{2}-\mathrm{H}_{2} \mathrm{O}$ will be a high pressure polymorph of xonotlite. However, little is known of the characteristics of the new phase.

As is well known, the X-ray diffraction patterns for polytypes in any species of calcium silicates and their hydrates have certain reflections in common, which indicate solely a "pseudo-cell". Considering the characteristics of crystal structure 
of xonotlite, Gard (1966) has shown the possibility of existence of four regular polytypes and two others with complete disorder within (001) plane in reciprocal space. He studied natural and synthetic xonotlites with electron diffraction technique and actually recognized the existence of polytypic structures, suggesting that the polytypes of xonotlite may reflect its formation temperatures. The studies on polytypes of the present xonotlite using electron microscope are being under way, so there is no available data to infer its formation temperatures.

As mentioned earlier, the present xonotlite represents the products of the latest stage of crystallization in the formation of jadeite-bearing albitites. The genesis of leucocrates including jadeitebearing albitites associated with serpentinites has been much debated by some investigators and various opinions have been expressed so far (Suzuki, 1940; Yoder, 1950; Yoder and Chesterman, 1951; Iwao, 1953; Seki, 1962). However, whatever the mode of genesis of the rocks may be, it is most likely that the crystallization of the xonotlite was a separated event from the formation of jadeite and other minerals, and it was formed from hydrous fluid which converted peridotite into serpentinite, probably after the formation of the host albitite.

The synthetic xonotlite crystallized out from the gel having the composition with $\mathrm{CaO}: \mathrm{SiO}_{2}=1: 1$ molar ratio at lower to moderate temperatures is characterized by higher content of water and is markedly different from the present xonotlite in the thermal behaviours. That is to say, its TG curve indicated that the weight loss due to dehydration and dehydroxylation occurred gradually and continuously in the wide temperature range from $200^{\circ}$ to $800^{\circ} \mathrm{C}$ (Komatsubara, 1970). Presumably, such a synthetic xonotlite contains water molecules loosly held in the interstices of crystals and on the surface of the particles in addition to the OH-group.

In conclusion, the physico-chemical environments under which the present xonotlite was formed may fall into the relatively high temperature and lower pressure region in its stability field and strongly alkaline conditions.

\section{ACKNOWLEDGEMENTS}

The writers wish to offer their sincere thanks to Prof. R. Sugiyama of Tôkai University, Prof. S. Nishida of Niigata University and Prof. S. Yajima of Waseda University for their continued interest and encouragment. Thanks are also due to Dr. A. Katô of the National Science Museum (Tokyo) for his valuable suggestion and helpful advice, and to Mr. T. Imayoshi of the museum for his kind gift of the present xonotlite.

They are also indebted to Dr. $\mathrm{H}$. Hayashi of National Institute of Industrial Health, who has kindly prepared the infrared absorption spectra of the present material, and to Mr. T. Iwai of X-ray Application Laboratory, Rigaku Denki Co., who has kindly given assistance in the course of the $\mathrm{X}$-ray studies.

Finally, the writers wish to acknowledge partial financial support by Grant-in-Aid for Fundamental Scientific Research from the Ministry of Education, Japan, and the support by grant from "The Group Project Organized by Science and Engineering Research Laboratory" of Waseda University.

\section{REFERENCES}

Banno, S. (1958), Glauchophane schists and 
associated rocks in the Ohmi district, Niigata Prefecture, J. Geol. Geogr., 29, 29-44.

Berman, H. (1937), Constitution and classification of the natural silicates, Amer. Mineral., 22, $342-408$.

Buckner, D.A., Roy, D.M. and Roy, R. (1960), Studies in the system $\mathrm{CaO}-\mathrm{Al}_{2} \mathrm{O}_{3}-\mathrm{SiO}_{2}-\mathrm{H}_{2} \mathrm{O}$ (II): The system $\mathrm{CaSiO}_{3}-\mathrm{H}_{2} \mathrm{O}$, Amer. J. Sci., 258, 132-147.

Chihara, K. (1958), Jadeite from Omi, Nigata Prefecture,Prof. Yoshiharu Fujimoto's Memorial Volume, (in Japanese with English abs.) 459-466.

Chihara, K. (1960), Jadeite from the Ohmi-Kotaki district, Niigata Prefecture (in Japan.), Niigataken Bunkazai Chôsahokokusho, 6, 35-78.

Chihara, K. (1970), Mineralogy and paragnenesis of jadeites from Omi-Kotaki area, central Japan (abs.), Collected Abs., IMA-IAGOD Meeting '70, 159.

Chihara, K. (1971), Mineralogy and paragenesis of jadeites from Omi-Kotaki area, central Japan, Mineral. Soc. Japan., Special Paper, No. 1, Proc. IMA-IAGOD Meetings '70, IMA Volume, 147-156.

Dana, E.S. (1909), Dana's System of Mineralogy, 6th Ed., John Wiley \& Sons, New York.

Dent, L.S. and Taylor, H.F.W. (1956), The dehydration of xonotlite, Acta Crystallogr., 9, 1002-1004.

Eakle, A.S. (1921), Jurupaite - A new mineral, Amer. Mineral., 6, 107-109.

Gard, J.A. (1966), A system of nomenclature for the fibrous calcium silicates, and a study of xonotlite polytypes, Nature, 190, 1078-1079.

Iwao, S. (1953), Albilite and associated jadeite rock from Kotaki district, Japan: A study in ceramic raw material, Geol. Surv. Japan, Rept., 153, 1-25.

Kawano, Y. (1939), A new occurrence of jadeite in Japan, and its chemical properties (in Japan.), J. Japan. Assoc. Petr. Min. Econ. Geol., 22, 195-201.

Kawada, S. (1954), Stratigraphical and palaeontological studies of Omi limestone in the Itoigawa district, Niigata Prefecture (in Japan. with English abs.), Bull. Geol. Mineral. Inst, Tokyo Kyoiku Daikagu (Tokyo Univ. of Educat.), 7, 15-27.

Komatsubara, M. (1970), Calcium silicate hydrate for building materials and thermal insulations (in Japan.), Ceramics, 5, 114-121.

Larsen, E.S. (1917), Eakleite, a new mineral from California, Amer. J. Sci., 43, 464-465.

Mamedov, Kh. S. and Belov, N.V. (1955), The crystal structure of xonotlite (in Russ.), Doklady Akad. Nauk SSSR, 104, 615-618. and - (1956), The crystal structure of wollastonite (in Russ,). Doklady Akad. Nauk SSSR, 107, 463-466.

Megaw, H.D. and Kelsey, C.H. (1956), Crystal structure of tobermorite, Nature, 177, 390391.

Ohmori, K. (1939), Optical properties of Japanese jade (in Japan.), J. Japan. Assoc. Min. Petr. Econ. Geol., 22, 201-212.

Otsuka, R., Imai, N., Chihara, K. and Nakamura, T. (1968), Xonotlite from the Ohmi district, Niigata Prefecture, Japan (abs. in Japan.), J. Geol. Soc. Japan, 74, 131-132.

Pistorius, C.W.F.T. (1963), Thermal decomposition of protlandite and xonotlite to high pressures and temperatures, Amer. J. Sci., 261, 79-87.

Saito, H., Otsuka, R., Iwata, S. and Tsuchimoto, K. (1964), An apparatus for combined thermogravimetry, derivative thermogravimetry and differential thermal analysis Bull. Sci. and Eng'ng. Res. Lab., Waseda Univ., 27, 26-32.

Seki, Y. (1962), Mafic and leucocratic rocks associated with serpentinite of Kanasaki, Kanto mountains, central Japan, Japan. J. Geol. Geogr., 33, 15-31.

Suzuki, J. (1940), On the leucocratic rocks associated with serpentine in Hokkaido, Japan (in Japan.), I, II, J. Japan. Assoc. Min. Petr. Econ. Geol., 23, 65-80, 124-142.

Switzer, G., Axelrod, J.M., Lindberg, M.L. and Larsen, E.S. (1948), Tables of $d$-spacings for angle $2 \theta$ (3rd ed.), U.S.G.S., Circ., 29.

Taylor, H.F.W. (1954), The identity of jurupaite and xonotlite, Mineral. Mag., 30, 338-341.

Taylor, H.F.W. and Howison, J.W. (1957), Relationships between calcium silicates and clay minerals, Clay Miner. Bull., 3, 98-111.

Taylor, H.F.W. (1958), The dehydration of tobermorite, Proc. 6th Nat'l. clay Conf., U.S.A., Barkley on Clays and Clay Minerals (1957), 101-109.

Taylor, H.F.W. (1959), The transformation of tobermorite into xonotlite, Mineral. Mag., 32. $110-116$.

Yoder, H.S., Jr. (1950), Jadeite problem, Amer. J. Sci., 248, 225-248, 312-334.

Yoder, H.S., Jr. and Chesterman, C.W. (1951), Jadeite of San Benito County, California, California Div. Mines, Special Rept. 10- $C$. 


\section{新潟県青海地域産ソノトラ石について}

今井 直哉・大冢 良平・茅原一也・中村 忠腈·田中 耕平

新溤県青海地域橋立の “ヒスイ谷”で，含ヒスイ輝石・曹長石岩の転石中に脈状をなして現出するソノトラ 石が蝺者らにより検討された。。の論文では，その産状，光学的性質，化学組成，X 線回折データ，熱分析デ 一タおよび赤外吸収スペクトルが示された。 Mamedov と Belov $(1955,1956)$ が提起した $\left(\mathrm{Si}_{6} \mathrm{O}_{17}\right)_{\infty} の$ 複鎖 構造を骨格とする単斜格子 (“Pseudo-cell”) 飞含まれる原子数汃ら算出された理想式は， $\mathrm{Ca}_{6}\left(\mathrm{Si}_{6} \mathrm{O}_{17}\right)(\mathrm{OH})_{2}$, $Z=2$ となる。とれにもとついて，O=19とし，その化学分析值から構造式を計算すると以下のようになる。 $\mathrm{Ca}_{5.83} \mathrm{Na}_{0.01}\left(\mathrm{Si}_{5.99} \mathrm{Al}_{0.01}\right)_{6.00} \mathrm{O}_{19.00} \mathrm{H}_{2.33}$

含水石灰珪酸塩類は化学組成において単調であるが，その結晶構造は複雑であり，同一鉣物種についても多数 の多型が存在する可能性をしつ(Gard，1955)。とのソノトラ石についても Gard が示したいずれの多型を含む か，現在電子回折法により検即中である。 